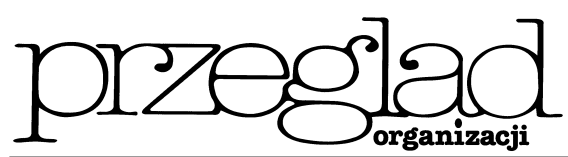

\title{
Zarządzanie wartością dla klienta w organizacji o rozmytych granicach
}

https://doi.org/10.33141/po.2005.02.09

Przegląd Organizacji, Nr 2 (781), 2005, ss. 39-41

www.przegladorganizacji.pl

Maciej Mitręga Towarzystwo Naukowe Organizacji i Kierownictwa (TNOiK)

Relacje z klientem stanowią jedynie element sieci relacji różnych podmiotów, w której funkcjonuje przedsiębiorstwo. Sieć ta obejmuje m. in. pracowników, inwestorów, dostawców, pośredników i media. Przedsiębiorstwo jest w gruncie rzeczy kategoria abstrakcyjna (swoistym abstraktem społecznym), choć posiada również cechy materialne. Dobra i usługi, wyposażenie, budynki, pracownicy to materialne dowody istnienia przedsiębiorstwa. Jednak ograniczenie widzenia przedsiębiorstwa do tych łatwo mierzalnych czynników byłoby zwyczajnym uproszczeniem. To, co konstytuuje całość przedsiębiorstwa, to bieżące relacje z podmiotami rynkowymi, czyli zmienne połączone w całościowy system. Struktura organizacji jest płynna w zależności od tego, czyj punkt widzenia w danej sytuacji przyjmiemy: właścicieli kapitału, kadry zarządzającej, klientów czy też może administracji lokalnej. W marketingowej koncepcji zarządzania przedsiębiorstwem traktowanie stosunków z klientem jako kluczowych w ramach sieci rynkowych relacji sprzyja konsolidacji działań wielu grup interesariuszy.

W przeciwieństwie do marketingu tradycyjnego, który koncentrował się na korzyściach materialnych uzyskiwanych w wyniku pojedynczych transakcji, współczesny marketing akcentuje znaczenie symbolicznego wymiaru długoterminowych stosunków między sprzedawcą a nabywcą. Przyjmuje się, że menedżerowie powinni zwracać szczególną uwagę na pozaekonomiczne i subiektywne uwarunkowania zachowań konsumentów i uzupełniać tradycyjne wskaźniki efektywności działań marketingowych (jak np. udział w rynku) pomiarami złożonych kategorii psychologicznych diagnozujących emocjonalny ton relacji z klientem. Przedsiębiorstwo powinno nieustannie kształtować relacje z własnymi pracownikami i innymi podmiotami w otoczeniu w celu zwiększenia wartości dostarczanej nabywcy ostatecznemu.

Zmiany zachodzace $\mathrm{w}$ teorii marketingu dobrze wpisują się w koncepcje nowego typu organizacji, w których praca organizowana jest wokół procesów i organizujących je zespołów, co oznacza odejście od klasycznej struktury funkcjonalnej i delegowanie decyzji oraz odpowiedzialności i przekazanie kontroli w ręce osób realizujących dany proces" ${ }^{11}$. Postrzeganie przedsiębiorstwa przez pryzmat sieci relacji z różnymi podmiotami realizuje się najpełniej w metaforze organizacji o rozmytych granicach.
Organizacja o rozmytych granicach jest to „...system, w ramach którego kluczowe zasoby, procesy i aktorzy funkcjonują i są zarządzani w sposób, który wykracza poza formalne struktury organizacyjne i oficjalną sprawozdawczość finansową" ${ }^{2)}$.

Struktura tak rozumianej organizacji stanowi sieć, która obejmuje „bazę”, czyli przedsiębiorstwo główne i przywódcę-wizjonera (imaginator) oraz jego „mapę strategiczną". Ta ostatnia składa się z:

- misji, która stanowi spoiwo całej sieci;

- unikatowej kultury organizacyjnej;

- bazy klientów, którzy są związani z organizacją poprzez systemy produkcji, dystrybucji, komunikacji i/bądź płatności;

- firm kooperujących i innych podmiotów, które są dostarczycielami niezbędnych zasobów.

Aby zachować integralność i przewage konkurencyjną, organizacja o rozmytych strukturach posiada „rdzeń", traktowany jako zbiór kluczowych kompetencji (rys. 1). W dłuższym okresie konieczne jest redefiniowanie kluczowych kompetencji tak, aby organizacja mogła sprostać wymogom złożoności i zmienności otoczenia.

Decentralizacja uprawnień i odpowiedzialności w strukturze organizacyjnej, a także wyodrębnienie spółek zależnych, strategicznych jednostek biznesu i innych „centrów zysku i kosztów” sprawiają, że przedsiębiorstwo staje się zbiorem wielu różnych organizacji. Zbiór ten stanowi całość połączoną różnego rodzaju więzami:

- prawnymi - wspólna marka, podatki i okresowa sprawozdawczość,

- finansowymi - wspólne planowanie wydatków,

- operacyjnymi-wspólna codzienna współpraca z dostawcami, klientami i innymi partnerami,

- strategicznymi - wspólne projekty badawczo-rozwojowe,

- ekologicznymi - wspólna odpowiedzialność za skutki działań przedsiębiorstwa z perspektywy prawnych uregulowań ochrony środowiska naturalnego ${ }^{3)}$.

Rdzeń organizacyjny stanowią zazwyczaj: unikatowe dobro lub usługa, zdolność do innowacji, oryginalne metody działań marketingowych lub wyjątkowe możliwości finansowania. Na bazie rdzenia budowane są alianse strategiczne z parterami biznesowymi. Dąży się do uzyskania dostępu do zasobów bez formalnego podwyższania wartości kapitału firmy.

$\mathrm{Z}$ perspektywy organizacji o rozmytych granicach podział zasobów ludzkich firmy na pracowników oraz 


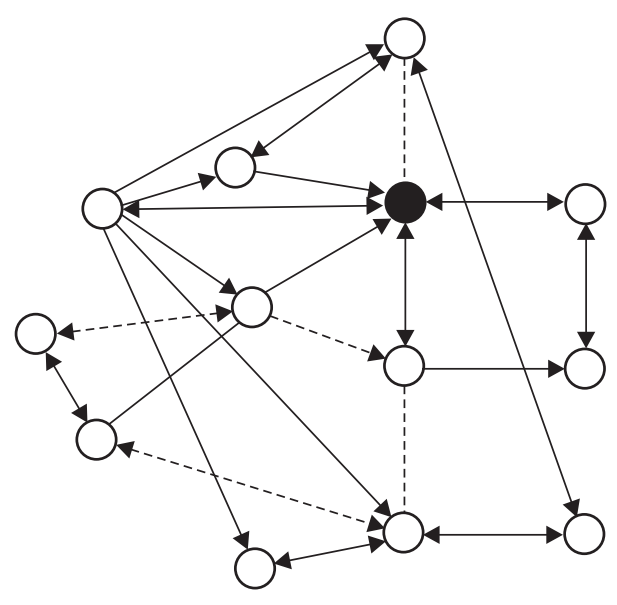

Kluczowe kompetencje

Rys. 1. Struktura organizacyjna jako sieć relacji o rozmytych granicach

Źródło: E. GUMMESSON, Making Relationship Marketing Operational, „Service Industry Management”, 5/5, 1994, s. 11 .

nie zatrudnionych, ale zaangażowanych członków sieci umożliwia przeprowadzenie interesujacego zabiegu poznawczego. W celu określenia stopnia „rozmycia” się całej struktury organizacyjnej stosuje się syntetyczny wskaźnik I/E (people involved - I, people employed - E). Im bardziej rozwinięte są relacje przedsiębiorstwa z różnymi grupami interesu (dostawcami, pośrednikami, instytucjami finansowymi, akcjonariuszami, konsumentami itd.), tym wyższa wartość wskaźnika I/E, a więc większy „potencjał ludzki” organizacji.

\section{Przykład}

Firma skandynawska Skandia AFS ${ }^{4)}$ (Assurance and Financial Services), która działa na rynku ubezpieczeń na życie i funduszy emerytalnych, przedstawia się jako organizacja obejmujaca milion klientów; alianse $z 65$ tys. niezależnych brokerów ubezpieczeniowych $i$ banków, 2 tys. pracowników oraz 60-osobowa kadrę zarzadzajaca. Jedna z gtównych przyczyn spektakularnego sukcesu szwedzkiej firmy byto wykorzystanie elementów koncepcji tzw. kapitatu intelektualnego w zakresie rachunkowości aktywów niematerialnych (m.in. kapitatu relacji z innymi podmiotami).

W celu określenia stopnia „rozmycia” się struktury organizacyjnej Skandii można wykorzystać wskaźnik $\boldsymbol{I} / \boldsymbol{E}$, gdzie I oznacza liczbe zatrudnionych pracowników, a $\boldsymbol{E}$ liczbę wszystkich osób zaangażowanych $w$ realizację strategii marketingowej. Im wyższy kapitat relacji przedsiębiorstwa $z$ różnymi grupami interesu, tym wyższa wartość wskaźnika I/E. W Skandii wskaźnik I/E jest wysoki i wynosi 32 (65000/2 060), wskazujac na bardzo wysoki stopień „rozmycia” się organizacji. W dodatku, gdybyśmy potraktowali wszystkich klientów jako zaangażowany zasób ludzki, wskaźnik ten wzróstby do 51!

Metafora organizacji o rozmytych granicach podkreśla znaczenie wielowymiarowych i nieliniowych (częściowo nieprzewidywalnych) zależności zachodzących wewnątrz i na zewnątrz struktury organizacyj- nej. W warunkach współczesnego wysoce złożonego otoczenia stosowne wydaje się postrzeganie przedsiębiorstwa nie tyle jako podmiotu dwustronnie oddziałującego, ale raczej zintegrowanego $\mathrm{z}$ otoczeniem poprzez sieci wielostronnych powiązań.

\section{Przykład}

W drugiej potowie lat 90. Polskie Linie Lotnicze LOT zyskownie rozszerzyty zasięg swojej dziatalności, realizujac $w$ praktyce wizje organizacji o rozmytych granicach. Polskiej firmie udato się osiagnać pozycję lidera w Europie Środkowo-Wschodniej dzięki umiejętnym ksztattowaniu relacji zarówno $z$ przedsiębiorstwami (dostawcami sprzętu i bazy cateringowej, touroperatorami, agentami w kanale dystrybucji, klientami biznesowymi itd.), jak i wtasnymi pracownikami (wysoko ceniona jakość obstugi i serwisu poktadowego) oraz klientami indywidualnymi (zob. rys. 2).

Warto zwrócić szczególna uwagę, że dzięki porozumieniom code-share $z$ konkurencyjnymi liniami lotniczymi, American Airlines (1994) oraz Lufhansa (2002), LOT wprowadzit swoja oferte na najbardziej rentowne rynki na świecie, a uczestnictwo $w$ aliansie Qualiflyer Group umożliwito jego klientom zdobywanie nagród $w$ ramach programu lojalnościowego „Frequent Flyer”. Wysoko należy również ocenić wspótpracę naszego narodowego przewoźnika lotniczego z touroperatorami organizujacymi pakiety turystyczne. Dzięki niej udato się chociazby zaoferować rodzimemu turyście bardzo atrakcyjne cenowo przeloty czarterowe $w$ ramach podróży wypoczynkowych za granicę. Natomiast $w$ wyniku umiejętnego ksztattowania relacji $z$ tzw. dostawcami treści i firmami z branży IT udato się PLL uruchomić wysoce interaktywny $i$ zaawansowany $w z a-$ kresie transakcji elektronicznych serwis internetowy.

W organizacji o rozmytych granicach pomiędzy sprzedawcą i nabywcą dochodzi do wymiany następujących rodzajów wartości ${ }^{5)}$ :

- wartości związanych z wynikiem - dotyczą one otrzymywanych w pojedynczej transakcji produktów lub innych wartości materialnych ocenianych z punktu widzenia fizycznych atrybutów, dostępności i ceny, - wartości związanych z doświadczeniem - dotyczą one stanów psychologicznych związanych z procesem wymiany,

- wartości związanych z działaniami - dotyczą one dodatkowych (poza transakcją) czynności wykonywanych przez strony w procesie wymiany.

Organizacja o rozmytych granicach stanowi zbiór współzależnych podmiotów, które przyczyniają się do zwiększenia wartości całej organizacji poprzez interaktywne procesy i rywalizację z innymi organizacjami. Główną funkcją tak rozumianej sieci podmiotów jest interpretowanie w unikatowy sposób potrzeb nabywcy ostatecznego. Można to osiągnąc dzięki połączeniu specyficznych kompetencji wielu podmiotów (nawet $\mathrm{z}$ różnych branż) i zaoferowaniu złożonego produktu-usługi. W strukturze przedsiębiorstwa wyodrębnia się z reguły specjalnego pracownika (agenta) odpowiedzialnego za relację $\mathrm{z}$ podmiotami kluczowymi z punktu widzenia dostarczania wartości ostatecznemu nabywcy.

Zdolność przedsiębiorstwa do funkcjonowania w ramach rozmytej struktury może być podtrzymywana za pomocą dwóch metod: 


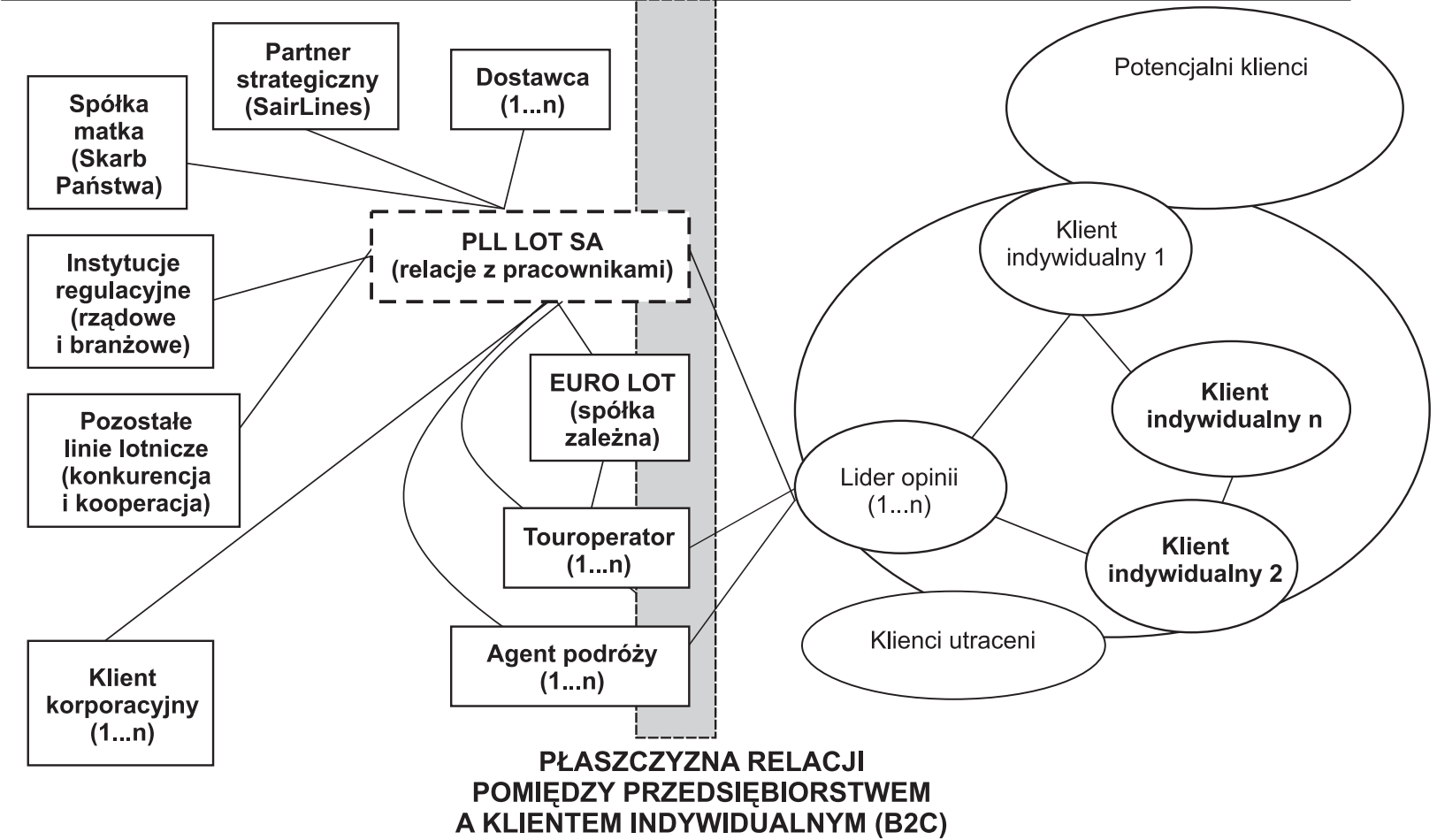

Rys. 2. Sieć relacji przedsiębiorstwa o rozmytych granicach na przykładzie PLL LOT SA Źródło: opracowanie własne.

- specjalizacji i maksymalnym wykorzystaniu wybranych kompetencji (np. specjalizacja w zakresie trudnych do naśladowania czynności, które są niezbędne do funkcjonowania całej sieci relacji),

- uzyskiwania kontroli nad działaniami podejmowanymi przez inne podmioty (np. posiadanie największej wiedzy o funkcjonowaniu sieci relacji i zarządzanie tą wiedzą w celu uzyskania przewagi $)^{6}$.

Należy oczywiście pamiętać, że zarówno przedsiębiorstwo, jak i konsument są zaangażowani w swoje własne procesy kreacji wartości. Procesy te sa specyficzne, ponieważ obejmują innego rodzaju czynności. Aby podtrzymywanie relacji firma - klient było celowe z punktu widzenia obu stron, wymiana, do której dochodzi, musi wzmacniać te procesy ${ }^{7}$.

Celem przedsiębiorstwa w ramach sieci rynkowych relacji nie jest dostarczanie konsumentowi wartości, ale raczej zmobilizowanie go do wykreowania wartości dla siebie przy wykorzystaniu oferty powstałej w wyniku współpracy wielu podmiotów.

\section{Przykład}

Klienci firmy Oriflame umożliwiaja przedstawicielowi firmy ,zainstalowanie” na kilka godzin punktu sprzedaży kosmetyków w ich wtasnych domach; klienci firm konsultingowych umożliwiaja doradcom dostęp do swojego biura oraz interakcji z personelem, a klienci banków on-line wykorzystuja funkcje dosteppne na witrynie $W W W w$ zastępstwie indywidualnych konsultacji $z$ personelem.

Wykreowanie wyróżniajacej się na rynku oferty bardzo często wymaga zaangażowania klientów, dostawców i zawiązania aliansów w biznesie. W tym sen- sie jedynym trwałym źródłem przewagi konkurencyjnej staje się zdolność do zaprojektowania i utrzymania organizacji o rozmytych granicach. Firma powinna nie tylko ulepszać swoją ofertę, ale także czynić starania na rzecz wzrostu wiedzy i umiejętności klientów i swoich partnerów w biznesie według zasady ${ }^{8)}$ :

„Aby wygrać, przedsiębiorstwo musi napisać scenariusz, zmobilizować i wyszkolić aktorów i uczynić klienta ostatecznym arbitrem swego sukcesu lub porażki”.

dr Maciej Mitręga

Katedra Badań Rynkowych i Marketingowych Akademii Ekonomicznej w Katowicach

\section{PRZYPISY}

1) T. ŻABIŃSKA, Wybrane modele strategii marketingowych $w$ ustugach i turystyce na tle ich paradygmatów, [w:] Modele strategii marketingowych, Wybrane ujęcia paradygmatyczne $i$ sektorowe, red. L. ZABINSKI, Akademia Ekonomiczna w Katowicach, Katowice 2000, s. 58.

2) B. HENDBERG, G. DAHLGREN, J. HANSSON, N.-G. OLVE, Imaginära organizationer (Imaginary Organizations), Liber-Hermonds, Malmö 1994, s. 16.

3) E. GUMMESSON, Total Relationship Marketing, Rethinking Marketing Management: From 4Ps to 30Rs, Butterworth-Heinemann, Oxford 2000, s. 212.

4) Przykład zaczerpnięty z: E. GUMMESSON, Total Relationship Marketing, op.cit., s. 216-217.

5) U. JÜTTNER, H. P. WERBLI, Relationship Marketing from a Value System Perspective, [w:] Advances in Relationship Marketing, red. A. PAYNE, Kogan Page, London 1995 , s. 229

6) Tamże, s. 233-236.

7) K. STORBACKA, The Nature of Customer Relationship Profitability, Swedish School of Economics and Business Administration, Helsingfors 1994, s. 62.

8) R. NORMANN, R. RAMIREZ, From Value Chain to Value Constellation: Designing Interactive Strategy, „Harvard Business Review", July-August 1993, s. 69. 